\title{
Police Leadership During a Pandemic
}

\author{
Matthew Torigian*
}

Canadians vilified Prime Minister Kim Campbell in 1993, when she reportedly quipped, "An election is no time to discuss serious issues." Days later, the Prime Minister clarified that what she really meant was that 47 days of an election campaign is not enough time to discuss serious issues. We still argue today about the impact such a statement had on the election, with some suggesting it led to a thrashing at the polls, while others suggest Canadians were just angry with the policies of her predecessor, Prime Minister Brian Mulroney. Regardless, her statement was met with disdain by the Canadian media of the day, and rightly so. Would the leader of a police service say the same thing in our situation today? Isn't now exactly the time to discuss a serious issue, such as whether the police have the moral authority to enforce extraordinary legal measures, and whether public health knowledge about community safety and well-being is a better guide than older ideas about "public order"?

Three elements readily come to mind to help us address these questions. Namely, the role of the police; the role of policing; and, perhaps most importantly, the role of police leaders amid these challenging and unprecedented times.

Legislation may be the simple avenue to answer the first question of what the police can or might do during these current events. Be it the Emergencies Act, the Quarantine Act, or respective pieces of provincial legislation, the legal authorities for police are clearly defined. As an example, Ontario's Emergency Management and Civil Protection Act (EMCPA) provides the necessary authorities for police, along with the range of penalties for the courts, in the event that a person or business fails to comply with an Order made under the relevant section of the EMCPA. But what about choices and strategies for the deployment of police resources in response to the Order, or the discretion of police officers during the enforcement of such investigations, along with community engagement strategies, or the creative use of technology? How are police leaders, and executives, chiefs, and boards, managing these matters?

The role of the police might take into consideration a pivot from traditional core functions to a more flexible response or might even alter standard operating procedures for everyday events such as 9-1-1 calls. Think tanks and police associations, along with both private and government agencies, have already come together to discuss these questions and offer guidelines and advice for police should they find themselves enforcing laws (or Orders) that represent a significant departure from their usual duties. Although the circumstances of these investigations and situations may be unique to the times, the roles, the operational standards, and the oversight expectations for police and police leaders need not be. Leaders need to be clear that peace and order go hand in hand with principles of good governance.

As to the second question, moving more broadly to the role of policing in our society, Canada is already leading the way in shaping a new policing paradigm for the 21st Century. Our own work in the Global Justice Lab, at the Munk School of Global Affairs and Public Policy, confirms this as we continue to engage with police and justice leaders worldwide. Community safety and well-being has become the lexicon, while multi-sector collaborations, information sharing, upstream interventions, data and evidence-based decision making, research, insight, and oversight have become the practices and studies accompanying and defining the mobilization of communities and community safety. A comprehensive set of reforms, to be sure. This does not come without a lot of work, including numerous symposiums, colloquia, and workshops involving a broad range of actors. It has been happening in earnest in Canada through the better part of the last decade. The shared responsibility for the well-being of our communities does not redefine traditional leadership roles but, rather, creates the environment for leaders to step forward in new ways. Traditional lanes of responsibility are now integrated and dovetail with non-traditional areas of responsibility. Traditional leadership alliances must actively and publicly partner with non-traditional colleagues, now more so than ever.

During the fluidity of a crisis, we cannot spend valuable time debating the purpose, scope, or role of policing. Yet we are all too aware that coerced compliance produces bad outcomes. Now is the time for big bold ideas in policing that move us away from an older model of public order. In Canada, we are lucky to have begun the conversation and subsequent reform years ago. Tactical responses to these unprecedented circumstances make perfect sense. Current discussions about safeguarding community trust in our police services whilst enforcing unfamiliar laws such as curfews, or leaning back to debate definitions of core policing, seem ill-timed when, really, at the core for all public services is the health and wellbeing of Canadians. Perhaps this is what Prime Minister Campbell actually meant, but she may have inadvertently left out a valuable constituent of the triad... the opportunity for leaders to truly lead.

Winston Churchill, perhaps England's most revered yet still controversial Prime Minister, is often quoted and often credited with providing brave and steady leadership during

Correspondence to: Matthew Torigian, Munk School of Global Affairs and Public Policy, University of Toronto, 315 Bloor Street West, Toronto, ON M5S 0A7. E-mail: matthew.torigian@utoronto.ca D DOI: http://dx.doi.org/10.35502/jcswb.126 
that country's "darkest hour." Although unconventional in style, he was arguably textbook in demonstrating what leadership looks like during times of difficulty. The role of leadership cannot be defined by the profession or occupation of its incumbent. We have all witnessed extraordinary leadership in recent months. Sadly, the opposite is also true. Police leaders are no exception to either.

There are clear and precise operational matters that require clarification, adjustment, and in some instances, suspension. These must always be secondary to the well-being and safety of all members within the police service. In the parlance of first responders, "guaranteed arrival" means simply that you can't help someone else if you die getting there. Every police leader must be visible, present (physically or virtually), and must communicate clearly to reinforce the values, mission, and vision of the service. Operational changes, such as flexibility in working conditions, discretionary powers, or the training and education of new powers and authorities, comes second to the mental well-being of those who we all rely upon during these difficult times and the very clear health risks that may impact them.
Knowing that our police leaders are standing alongside fellow community leaders and, in particular, working closely with the Public Health system is comfort to many, and signals that all of our work over the past number of years is paying new dividends when they are needed most. As the saying goes for all leaders, and especially at times like these, no one cares how much you know, people just want to know how much you care.

Such is true for police service members, for all formal and informal leaders in every human service profession and among the community alike. To paraphrase Winston Churchill, even amid crisis, courageous leaders can and will find new ways toward a better future.

CONFLICT OF INTEREST DISCLOSURE

The author has no conflicts of interest to declare.

\section{AFFILIATIONS}

*Distinguished Fellow, Munk School of Global Affairs and Public Policy, University of Toronto, Toronto, ON

*Senior Contributing Editor, Journal of Community Safety and Well-Being 